\title{
Biomonitoring of trace element accumulation in plants growing at Murat Mountain
}

\author{
I. Ugulu $\cdot$ Y. Dogan $\cdot$ S. Baslar $\cdot$ O. Varol
}

Received: 14 February 2011/Revised: 28 June 2011/Accepted: 19 November 2011/Published online: 12 April 2012

(c) CEERS, IAU 2012

\begin{abstract}
The purpose of this study is to determine the present levels of atmospheric trace element pollution in the Murat Mountain of Aegean Region in the western part of Turkey. Therefore, 29 different plants were selected as potential biomonitors of trace elements including nickel, zinc, iron, lead, cadmium and manganese $(\mu \mathrm{g} / \mathrm{g}$, dry weight). The samples were collected from two different heights of Murat Mountain. Atomic absorption spectrometry was used to determine the concentrations of trace elements. The mean concentrations determined at $1,000 \mathrm{~m}$ altitude ranged from 0.139 to $4.518,0.223$ to $0.986,0.359$ to $6.930,0.443$ to 0.727 and 0.077 to $3.222 \mu \mathrm{g} / \mathrm{g}$, dry weight, for nickel, zinc, iron, lead and manganese, respectively. At $1,600 \mathrm{~m}$ altitude, the values ranged from 0.191 to $6.248,0.302$ to $1.008,2.387$ to $8.896,0.345$ to 0.570 and 0.195 to $3.502 \mu \mathrm{g} / \mathrm{g}$, dry weight, for nickel, zinc, iron, lead and manganese, respectively. No cadmium was found at both altitudes. For determination of existence of any differences between the averages of the herbaceous and woody plants, comparisons were made by the independent sample $t$ test. In the statistical analysis, comparison of trace element pollution values of herbaceous and woody
\end{abstract}

I. Ugulu ( $₫)$

Department of Biology, Necatibey Faculty of Education, Balikesir University, 10100 Balikesir, Turkey

e-mail: ilkerugulu@mynet.com

Y. Dogan · S. Baslar

Department of Biology, Buca Faculty of Education,

Dokuz Eylul University, Buca, 35150 Izmir, Turkey

O. Varol

Department of Biology, Faculty of Arts and Sciences,

Mugla University, 48000 Mugla, Turkey plants for nickel, lead and manganese was significant $(P<0.05)$, while it was not for iron and zinc.

Keywords Heavy metal accumulation - Bioindicator . Plant · Pollution

\section{Introduction}

Environmental toxicology deals with toxic substances, their adverse effects on living organisms, and environmental pollution assessment. Chemical contamination may affect ecosystems, causing changes in the functions of particular organisms or modifying the physical properties of the environment (Gadzala-Kopciuch et al. 2004). The relationships between the xenobiotic, environment and organism may, under certain conditions, result in the degradation of toxic compounds through their modification, inducing changes in the environment and producing a negative effect on living organisms (Brandys et al. 1999). Toxic chemical substances introduced into the environment may be transported by the air, water and living organisms. These substances can be found in the whole biosphere. They become a part of the natural biogeochemical cycle and accumulate in the food chain. They also affect humans, causing various poisonings, toxicoses, and even neoplastic diseases (Nalecz-Jawecki and Sawicki 1998).

All components of the biosphere are polluted by a variety of inorganic and organic xenobiotics as a result of anthropogenic activities and alter the normal biogeochemical cycling. Among them, trace element contamination of the biosphere has increased sharply since 1900 and poses major environmental and human health problems worldwide (Prasad and Freitas 2003). Although trace elements are natural components of the environment, they are 
emitted into the environment in different ways; through natural sources such as continental dust, volcanic dust and gas, sea spray and biogenic particles or through anthropogenic inputs, i.e., transportation, industry, fossil fuels, agriculture, and other anthropogenic activities (Aksoy et al. 2000). For most of the toxic trace metals, anthropogenic inputs are more important than natural sources. Maninduced mobilization of trace metals into the biosphere has become an important process in the global geochemical cycling of these elements. This effect is most evident in urban areas where several stationary and mobile sources (industrial activities, energy production, construction, urban waste treatment, vehicle exhausts) release large quantities of trace metals into the atmosphere, soil and aquatic ecosystems very often exceeding the natural emission rates (Samura et al. 2003).

Biological monitoring within a quality control program involves the systematic use of living beings for obtaining quantitative information on changes in the environment, often due to anthropogenic activities (Bargagli 1998). Biological responses can be considered more representative than data supplied by chemical or physical detectors, in that they are spatially and temporally extensive; moreover, they allow for estimating both the levels of pollutants and, even more important, the impact on biological receptors (Calzoni et al. 2007). For this reason, in order to evaluate, minimize and avoid detrimental effects of toxic metals, there has been an emphasis in the use of natural bioindicators to monitor atmospheric quality in both urban and rural environments (Szczepaniak and Biziuk 2003; Ng et al. 2005).

\section{Plants as bioindicators}

Plant organisms play an important role in their natural habitats-they supply oxygen, control organic substance circulation and biological balance of the soil and bottom deposits, provide food and shelter to other organisms (Manning et al. 2002). Phytoindicators are more and more frequently used for ecosystem quality assessment due to their sensitivity to chemical changes in environmental composition and the fact they accumulate pollutants. The use of plants as bioindicators has many advantages, including low costs, the possibility of long-term sampling and high availability (Gadzala-Kopciuch et al. 2004). Moreover, using different types of vegetation, the levels of atmospheric trace metallic concentrations have been successfully monitored (Dogan et al. 2007; Onder et al. 2007). Biomonitoring provides the cheapest and simplest method for monitoring trace metals elements in the atmosphere (Kaya and Yaman 2008; Cayir et al. 2008).

Regarding the use of plants as bioindicators, many studies have been carried out alongside the urban and rural habitats in Turkey in this direction (Baslar et al. 2003, 2005; Yilmaz and Zengin 2004; Yilmaz et al. 2006; Dogan et al. 2007, 2010; Cayir et al. 2008; Ozturk et al. 2008; Huseyinova et al. 2009). The samples collected in some of these studies have used mountainous areas as control group with the assumption that these are unpolluted (Baslar et al. 2003, 2005; Yilmaz and Zengin 2004; Dogan et al. 2007). Present investigation is important in terms of determining trace element levels in mountainous areas which are considered to be free of trace elements and, therefore, taken as reference.

\section{Materials and methods}

Study area

The Mt. Murat, the highest mountain in Kutahya and Usak provinces, creates a natural border between these two provinces (Fig. 1). It has many hills and plateau, and the highest among them is $2,312 \mathrm{~m}$. It is one of the highest mountains of the Aegean Region with this feature. Mountain is covered with pine forests are becoming scarce toward the peak. Hot water resources are located near the summit areas. These resources have been turned into thermal springs and spa centers by the various agencies and local people.

The location of the sampling points on steep slopes provides results depending on altitude rather than on horizontal distance (Zechmeister 1995). The samples were collected from 1,000 and $1,600 \mathrm{~m}$ above the sea level at a distance of $35-40 \mathrm{~km}$ away from the city center.

Collection and preparation of samples and chemical analysis

The plants were collected from 1,000- and 1,600-m altitudes during July-August 2006. A total of 29 plant species were collected on the windward side of the Mt. Murat, 15 species from $1,000 \mathrm{~m}$ and 14 species from $1,600 \mathrm{~m}$. The determination of the plant samples was carried out according to Davis (1965-1985), Davis et al. (1988) and Guner et al. (2001).

About $200 \mathrm{~g}$ of grown leaves of bushy species and about $200 \mathrm{~g}$ of aboveground parts of herbaceous plants were collected for analyses. The samples were dried in oven at $80{ }^{\circ} \mathrm{C}$ for $24 \mathrm{~h}$, milled in a micro-hammer cutter and fed through a $0.2-\mathrm{mm}$ sieve. The samples were stored in clean self-sealing plastic bags under silica gel desiccant. Contamination from the micro-hammer cutter was negligible during the grinding because it was washed after every grinding, first with absolute alcohol then with distilled water. 
Fig. 1 Geographical location of the study area

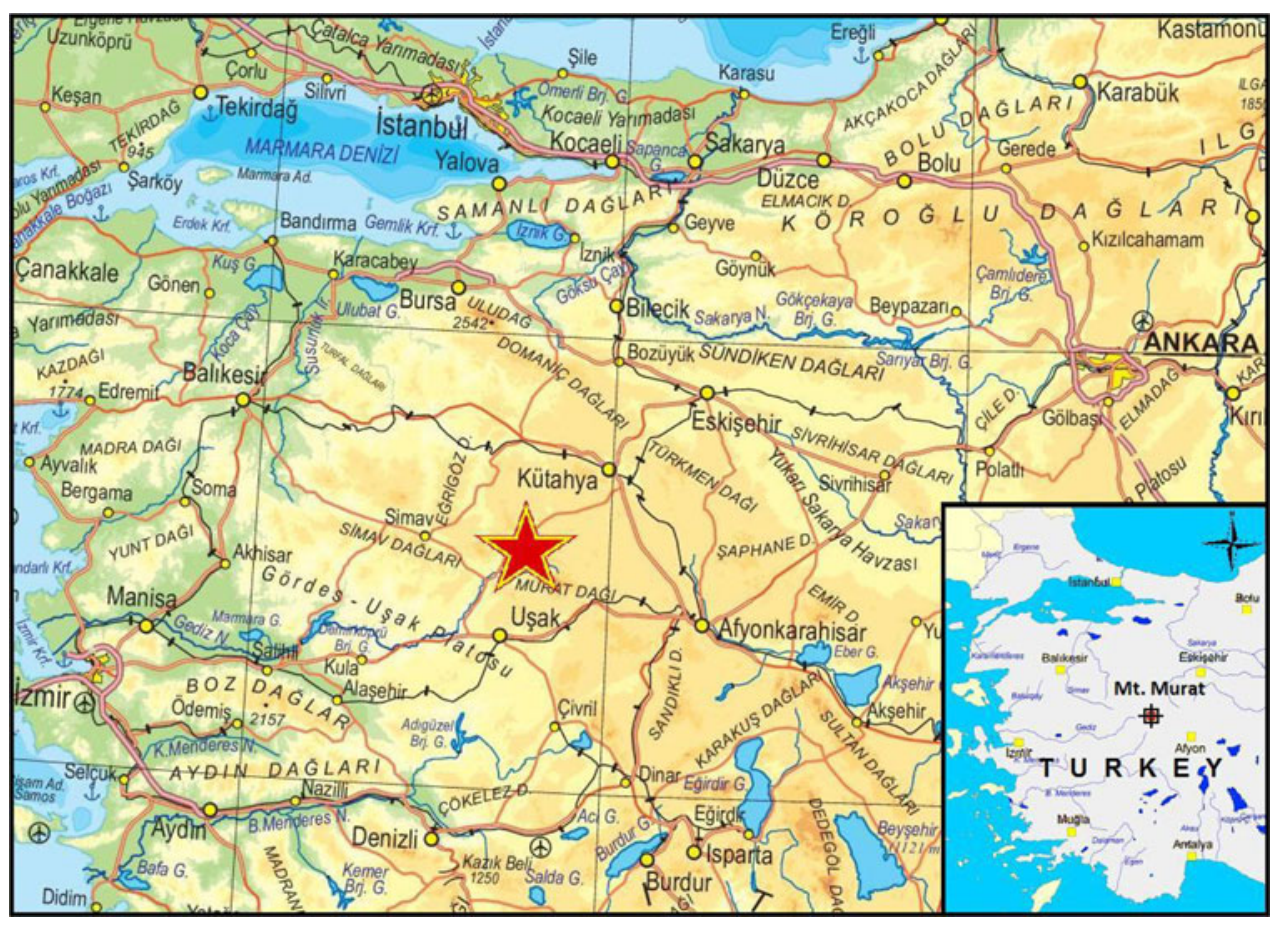

Wet digestion procedure

The method used for plant digestion is described by Perkin Elmer Corporation (Anonymous 1996). The digested samples were aspirated into an air-acetylene flame and the metals determined by flame atomic absorption spectrometry (FAAS). The reproducibility of the method used in decomposing the leaf samples was checked by carrying out a triplicate analysis. All samples were analyzed immediately after digestion.

\section{Reagents}

All chemicals used were of analytical reagent grade unless otherwise specified. Triple distilled water was used throughout the experiments. Working metal standard solutions were prepared just before use, by diluting the stock standard solution with water. Stock standard solutions were prepared from high purity metals, oxides or nonhygroscopic reagent grade salts using deionized distilled water and redistilled nitric or hydrochloric acids. The digestion method and the flame atomic absorption spectrophotometry (FAAS) analysis were validated by preparation of a multi-element standard solution (MESS) containing $1,000 \mathrm{mg} / \mathrm{l}$ of each metal.

\section{Instrumentation}

Determination of the metals was performed with Perkin Elmer Analyst 700 model flame atomic absorption spectrometer equipped with deuterium background correction, hollow cathode lamps $(\mathrm{HCl})$ and acetylene burner. The absorption measurements of the metals were performed under the conditions recommended by the manufacturer (Table 1). A Cole-Parmer microfiltration apparatus with membrane filter $(0.45 \mu \mathrm{m}$ pore size manufactured by Micro Filtration Systems) was used for the filtration of the aqueous phase before metal determination.

\section{Statistical data analysis}

Statistical significance was determined by the independent sample $t$ test. In the independent sample $t$ test, comparisons were made in order to determine whether there were any differences between the averages of the herbaceous plants and woody plants. Differences at $P<0.05$ were considered to be significant. A Statistical Package (SPSS 15.0) was used in the analysis of $t$ test for the data collected.

Table 1 Operating conditions for the analysis of trace elements using FAAS

\begin{tabular}{lllll}
\hline Metals & $\begin{array}{l}\text { Wavelength } \\
(\mathrm{nm})\end{array}$ & $\begin{array}{l}\text { Lamp current } \\
(\mathrm{mA})\end{array}$ & Flame & $\begin{array}{l}\text { Slit width } \\
(\mathrm{mm})\end{array}$ \\
\hline $\mathrm{Cd}$ & 228.8 & 6 & Air-acetylene & 0.7 \\
$\mathrm{Ni}$ & 232.0 & 30 & & 0.2 \\
$\mathrm{Zn}$ & 213.9 & 20 & & 0.7 \\
$\mathrm{Fe}$ & 248.3 & 30 & 0.2 \\
$\mathrm{~Pb}$ & 283.3 & 12 & 0.7 \\
$\mathrm{Mn}$ & 279.5 & 30 & 0.2 \\
\hline
\end{tabular}




\section{Results and discussion}

The concentrations of the trace elements $\mathrm{Cd}, \mathrm{Ni}, \mathrm{Zn}, \mathrm{Fe}, \mathrm{Pb}$ and $\mathrm{Mn}(\mu \mathrm{g} / \mathrm{g}$, dry weight) in plant samples from 1,000 and 1,600 $\mathrm{m}$ of Mt. Murat are given in Tables 2 and 3. The plant species used as biomonitor to investigate the levels of the trace elements were sampled with 29 different species at 1,000 and 1,600 m of height in the Mt. Murat. The levels of elements were determined by flame atomic absorption spectrometry. As a result of experiments carried out, the mean concentrations of $\mathrm{Ni}, \mathrm{Zn}, \mathrm{Fe}, \mathrm{Pb}$ and $\mathrm{Mn}(\mu \mathrm{g} / \mathrm{g}$, dry weight) ranged from 0.139 to $4.518,0.223$ to $0.986,0.359$ to $6.930,0.443$ to 0.727 and 0.077 to 3.222 , respectively, at an altitude of $1,000 \mathrm{~m}$ (Table 2). At an altitude of 1,600 m altitude, the mean concentration of $\mathrm{Ni}, \mathrm{Zn}, \mathrm{Fe}, \mathrm{Pb}$ and $\mathrm{Mn}$ ( $\mu \mathrm{g} / \mathrm{g}$, dry weight) ranged from 0.191 to $6.248,0.302$ to $1.008,2.387$ to $8.896,0.345$ to 0.570 and 0.195 to 3.502 , respectively (Table 3 ). No Cd values were determined in the samples collected from both heights.

The aggregation of investigated trace elements in plants collected from 1,000 $\mathrm{m}$ of the Mt. Murat was presented in Table 2. From the Table 2, it can be seen that Ni content was the highest in Alyssum fulvescens ssp. fulvescens $(4.518 \mu \mathrm{g} / \mathrm{g})$, and the lowest in Lolium temulentum $(0.139 \mu \mathrm{g} / \mathrm{g}) . \mathrm{Zn}$ content was the highest in Stachys cretica ssp. smyrnaea $(0.986 \mu \mathrm{g} / \mathrm{g})$, the lowest in L. temulentum $(0.223 \mu \mathrm{g} / \mathrm{g})$. It was determined that $\mathrm{Fe}$ content was the highest in Quercus cerris ssp. cerris $(6.930 \mu \mathrm{g} / \mathrm{g})$, whereas the lowest in L. temulentum $(0.359 \mu \mathrm{g} / \mathrm{g})$. In terms of $\mathrm{Pb}$ content, A. fulvescens ssp. fulvescens $(0.727 \mu \mathrm{g} / \mathrm{g})$ was the highest, and Cedrus sp. $(0.443 \mu \mathrm{g} / \mathrm{g})$ was the lowest. Mn content was the highest in A. fulvescens ssp. fulvescens $(3.222 \mu \mathrm{g} / \mathrm{g})$, the lowest in Cistus creticus $(0,077 \mu \mathrm{g} / \mathrm{g})$. In $1,000 \mathrm{~m}$, the highest values were recorded as $\mathrm{Ni}, \mathrm{Pb}$ and $\mathrm{Mn}$ in A. fulvescens ssp. fulvescens, $\mathrm{Zn}$ in S. cretica ssp. smyrnaea and $\mathrm{Fe}$ in $Q$. cerris subsp. cerris.

From the Table 3, it can be seen that $\mathrm{Ni}$ content was highest in A. fulvescens ssp. fulvescens $(6.248 \mu \mathrm{g} / \mathrm{g})$, whereas the lowest in Platanus orientalis $(0.191 \mu \mathrm{g} / \mathrm{g})$. In terms of $\mathrm{Zn}$ content, it was the highest in Celtis australis $(1.008 \mu \mathrm{g} / \mathrm{g})$, and the lowest in Inula orientalis $(0.302 \mu \mathrm{g} /$ g). Fe content was highest in Orobanche sp. $(8.896 \mu \mathrm{g} / \mathrm{g})$, and the lowest in Pinus nigra subsp. pallasiana $(2.387 \mu \mathrm{g} /$ g). It was seen that $\mathrm{Pb}$ content was highest in $P$. nigra subsp. pallasiana $(0.570 \mu \mathrm{g} / \mathrm{g})$, whereas the lowest in C. australis $(0.345 \mu \mathrm{g} / \mathrm{g})$. The highest Mn content was observed in Orobanche sp. $(3.502 \mu \mathrm{g} / \mathrm{g})$, while the lowest Mn content was in C. australis $(0.195 \mu \mathrm{g} / \mathrm{g})$. In $1,600 \mathrm{~m}$, $\mathrm{Ni}$ content was highest in A. fulvescens ssp. fulvescens, $\mathrm{Zn}$ was highest in $C$. australis, $\mathrm{Fe}$ and $\mathrm{Mn}$ was highest in Orobanche sp. and $\mathrm{Pb}$ was highest in $P$. nigra subsp. pallasiana.

In the statistical analysis, comparison of trace element pollution values of herbaceous and woody plants for $\mathrm{Ni}, \mathrm{Pb}$ and $\mathrm{Mn}$ was meaningful $(P<0.05)$, while it was not for $\mathrm{Zn}$ and Fe (Table 4). When the mean values of trace element

Table 2 Trace element contents in plants growing in the Mt. Murat $(\mu \mathrm{g} / \mathrm{g}$, dry weight) $(1,000 \mathrm{~m})$

\begin{tabular}{|c|c|c|c|c|c|}
\hline Plants & $\mathrm{Ni}$ & $\mathrm{Zn}$ & $\mathrm{Fe}$ & $\mathrm{Pb}$ & $\mathrm{Mn}$ \\
\hline \multicolumn{6}{|l|}{ Herbaceous } \\
\hline Achillea nobilis L. subsp. sipylea (O. Schwarz) Bässler & 2.959 & 0.660 & 5.678 & 0.524 & 2.076 \\
\hline A. fulvescens Sibth. \& Sm. subsp. fulvescens & 4.518 & 0.490 & 5.892 & 0.727 & 3.222 \\
\hline Bupleurum trichopodum Boiss. \& Spruner & 0.197 & 0.337 & 0.723 & 0.575 & 0.329 \\
\hline Euphorbia sp. & 0.340 & 0.556 & 4.049 & 0.533 & 0.280 \\
\hline Lolium temulentum $\mathrm{L}$. & 0.139 & 0.223 & 0.359 & 0.510 & 0.446 \\
\hline Muscari sp. & 0.849 & 0.472 & 3.211 & 0.457 & 0.153 \\
\hline Pimpinella anisum $\mathrm{L}$. & 1.174 & 0.843 & 3.962 & 0.449 & 0.530 \\
\hline Polygalla pruinosa $\mathrm{L}$. & 1.383 & 0.546 & 5.129 & 0.550 & 1.112 \\
\hline Stachys cretica L. subsp. smyrnaea Rech fil. & 1.568 & 0.986 & 4.165 & 0.499 & 0.552 \\
\hline Verbascum sp. & 1.481 & 0.655 & 4.684 & 0.490 & 0.652 \\
\hline Vicia cracca $\mathrm{L}$. & 0.204 & 0.520 & 2.635 & 0.483 & 0.191 \\
\hline \multicolumn{6}{|l|}{ Woody } \\
\hline Cedrus libani A. Rich. & 0.169 & 0.845 & 1.223 & 0.443 & 0.108 \\
\hline Cistus creticus L. & 0.266 & 0.649 & 3.823 & 0.513 & 0.077 \\
\hline Quercus cerris L. subsp. cerris & 0.298 & 0.649 & 6.930 & 0.701 & 0.141 \\
\hline Rhus coriaria $\mathrm{L}$. & 0.197 & 0.680 & 4.515 & 0.471 & 0.175 \\
\hline Min. & 0.139 & 0.223 & 0.359 & 0.443 & 0.077 \\
\hline Max. & 4.518 & 0.986 & 6.930 & 0.727 & 3.222 \\
\hline Mean & $1.04 \pm 0.32$ & $0.60 \pm 0.05$ & $3.79 \pm 0.49$ & $0.52 \pm 0.02$ & $0.66 \pm 0.22$ \\
\hline
\end{tabular}


Table 3 Trace element contents in plants growing in the Mt. Murat $(\mu \mathrm{g} / \mathrm{g}$, dry weight) $(1,600 \mathrm{~m})$

\begin{tabular}{|c|c|c|c|c|c|}
\hline Plants & $\mathrm{Ni}$ & $\mathrm{Zn}$ & $\mathrm{Fe}$ & $\mathrm{Pb}$ & $\mathrm{Mn}$ \\
\hline \multicolumn{6}{|l|}{ Herbaceous } \\
\hline Achillea nobilis L. subsp. sipylea (O. Schwarz) Bässler & 5.168 & 0.418 & 8.542 & 0.520 & 2.189 \\
\hline Alyssum fulvescens Sibth. \& Sm. subsp. fulvescens & 6.248 & 0.889 & 5.968 & 0.553 & 2.704 \\
\hline Buglossoides arvensis (L.) I.M. Johnston & 3.184 & 0.527 & 7.954 & 0.364 & 1.529 \\
\hline Euphorbia anacampseros Boiss. subsp. anacampseros & 1.956 & 0.846 & 5.314 & 0.484 & 0.615 \\
\hline Euphorbia rigida M. Bieb. & 3.326 & 0.833 & 8.792 & 0.449 & 3.309 \\
\hline Geranium pyrenaicum $\mathrm{L}$. & 2.839 & 0.567 & 4.752 & 0.568 & 1.479 \\
\hline Inula orientalis Lam. & 1.139 & 0.302 & 6.112 & 0.522 & 1.809 \\
\hline Myosotis alpestris F.W. Schmidt subsp. alpestris & 0.523 & 0.547 & 2.398 & 0.550 & 0.691 \\
\hline Orobanche sp. & 4.862 & 0.653 & 8.896 & 0.521 & 3.502 \\
\hline Verbascum sp. & 3.844 & 0.488 & 6.932 & 0.534 & 1.014 \\
\hline \multicolumn{6}{|l|}{ Woody } \\
\hline Celtis australis $\mathrm{L}$. & 0.363 & 1.008 & 4.029 & 0.345 & 0.195 \\
\hline Pinus nigra Arn. subsp. pallasiana (Lamb) Holmboe. & 0.484 & 0.504 & 2.387 & 0.570 & 1.038 \\
\hline Platanus orientalis L. & 0.191 & 0.693 & 2.797 & 0.434 & 0.307 \\
\hline Salvia sp. & 1.900 & 0.523 & 6.862 & 0.499 & 1.452 \\
\hline Min. & 0.191 & 0.302 & 2.387 & 0.345 & 0.195 \\
\hline Max. & 6.248 & 1.008 & 8.896 & 0.570 & 3.502 \\
\hline Mean & $2.57 \pm 0.52$ & $0.62 \pm 0.05$ & $5.83 \pm 0.61$ & $0.49 \pm 0.01$ & $1.55 \pm 0.27$ \\
\hline
\end{tabular}

Table 4 Statistical analysis values of herbaceous and woody plants

\begin{tabular}{|c|c|c|c|c|c|c|c|c|c|}
\hline \multicolumn{10}{|l|}{ Independent samples test } \\
\hline & \multicolumn{2}{|c|}{$\begin{array}{l}\text { Levene's test for equality } \\
\text { of variances }\end{array}$} & \multicolumn{7}{|c|}{$t$ test for equality of means } \\
\hline & \multirow[t]{2}{*}{$\mathrm{F}$} & \multirow[t]{2}{*}{ Sig. } & \multirow[t]{2}{*}{$t$} & \multirow[t]{2}{*}{$d f$} & \multirow[t]{2}{*}{$\begin{array}{l}\text { Sig. } \\
\text { (2-tailed) }\end{array}$} & \multirow[t]{2}{*}{$\begin{array}{l}\text { Mean } \\
\text { difference }\end{array}$} & \multirow[t]{2}{*}{$\begin{array}{l}\text { Std. error } \\
\text { difference }\end{array}$} & \multicolumn{2}{|c|}{$\begin{array}{l}95 \% \text { confidence interval } \\
\text { of the difference }\end{array}$} \\
\hline & & & & & & & & Lower & Upper \\
\hline \multicolumn{10}{|l|}{$\mathrm{Ni}$} \\
\hline Equal variances assumed & 10.714 & 0.003 & -2.183 & 27 & 0.038 & -1.793333 & 0.821410 & -3.478728 & -0.107939 \\
\hline Equal variances not assumed & & & -4.797 & 24.058 & 0.000 & -1.793333 & 0.373876 & -2.564878 & -1.021789 \\
\hline \multicolumn{10}{|l|}{$\mathrm{Zn}$} \\
\hline Equal variances assumed & 0.001 & 0.977 & 1.583 & 27 & 0.125 & 0.147717 & 0.093312 & -0.043744 & 0.339177 \\
\hline Equal variances not assumed & & & 1.562 & 5.723 & 0.172 & 0.147717 & 0.094573 & -0.086442 & 0.381875 \\
\hline \multicolumn{10}{|l|}{$\mathrm{Fe}$} \\
\hline Equal variances assumed & 0.069 & 0.794 & -1.412 & 27 & 0.169 & -1.582925 & 1.120667 & -3.882344 & 0.716494 \\
\hline Equal variances not assumed & & & -1.465 & 6.014 & 0.193 & -1.582925 & 1.080643 & -4.225646 & 1.059796 \\
\hline \multicolumn{10}{|l|}{$\mathrm{Pb}$} \\
\hline Equal variances assumed & 7.205 & 0.012 & -0.401 & 27 & 0.692 & -0.015775 & 0.039350 & -0.096515 & 0.064965 \\
\hline Equal variances not assumed & & & -0.249 & 4.369 & 0.815 & -0.015775 & 0.063404 & -0.186107 & 0.154557 \\
\hline \multicolumn{10}{|l|}{ Mn } \\
\hline Equal variances assumed & 5.526 & 0.026 & -1.809 & 27 & 0.082 & -0.895867 & 0.495296 & -1.912130 & 0.120396 \\
\hline Equal variances not assumed & & & -3.195 & 18.822 & 0.005 & -0.895867 & 0.280394 & -1.483115 & -0.308619 \\
\hline
\end{tabular}

pollution in herbaceous and woody plants were compared, the accumulation was higher in herbaceous plants for $\mathrm{Ni}$, $\mathrm{Pb}$ and $\mathrm{Mn}$, where there was a statistically meaningful difference. However, there was not a statistically meaningful difference for $\mathrm{Zn}$ and Fe mean accumulation values between herbaceous and woody plants. 
The West Anatolian region is one of the most important areas for industrialization, population density and traffic in Turkey. Rapid urbanization, increasing number of vehicles on the roads and industrialization has resulted in the increase of pollution in the region. Therefore, the plants, which are used as biomonitor to investigate the levels of the trace elements $\mathrm{Cd}, \mathrm{Ni}, \mathrm{Zn}, \mathrm{Fe}, \mathrm{Pb}$ and $\mathrm{Mn}(\mu \mathrm{g} / \mathrm{g}$, dry weight), were sampled with 29 different species at two different levels of height in the Mt. Murat.

Various researchers have explained the sources for accumulation of some other trace elements. For example, $\mathrm{Pb}$ and $\mathrm{Zn}$ originate mainly from anthropogenic activities such as burning of fossil fuels and mining activities (Alfani et al. 2000; Blok 2005; Oliva and Rautio 2005). Major anthropogenic sources of $\mathrm{Ni}$ are burning of coal and oil, production of $\mathrm{Cu}, \mathrm{Ni}$ and $\mathrm{Pb}$, mining operations, steel works and cement industry (Nriagu and Pacyna 1988). Loppi et al. (1999) have reported that plants were highly affected from contamination of soil by $\mathrm{Fe}$ and $\mathrm{Mn}$ in the Mediterranean climate zone, although airborne Mn originates mainly from soil (Bargagli et al. 2003; Oliva and Rautio 2005), Fe originates both from anthropogenic and natural sources (Oliva and Rautio 2005). According to the Osteras et al. (2000), Cd enters forest soils via atmospheric deposition, originating from burning of fossil fuels, mining activities and via spreading of lime and fertilizers, as such this could be the reason for the studied area because very little fossil fuels are used in this area, and traffic is negligible.

The accumulation of trace elements in plants' parts was investigated by various researchers in different parts of the world, as well as in Turkey. Among the results of other researchers, some of them are given below for comparison of the findings: Dijingova et al. (1995) (Cd 0.10-31.20 $\mu \mathrm{g} / \mathrm{g}, \mathrm{Ni}$ $0.50-4.9 \mu \mathrm{g} / \mathrm{g}, \quad \mathrm{Zn} 7-302 \mu \mathrm{g} / \mathrm{g}$, Fe 100-283 $\mu \mathrm{g} / \mathrm{g}, \quad \mathrm{Pb}$ 0.80-21.30 $\mu \mathrm{g} / \mathrm{g}, \mathrm{Mn} 44-405 \mu \mathrm{g} / \mathrm{g})$, Baslar et al. (2003) (Ni $0.88 \mu \mathrm{g} / \mathrm{g}$, Fe $57.28 \mu \mathrm{g} / \mathrm{g}, \mathrm{Pb} 1.4 \mu \mathrm{g} / \mathrm{g}$ ), Dogan et al. (2007) (Ni $3.56 \mu \mathrm{g} / \mathrm{g}$, Fe $486.35 \mu \mathrm{g} / \mathrm{g}, \mathrm{Pb} 4.59 \mu \mathrm{g} / \mathrm{g}$ ), Baslar et al. (2005) (Cd $1.7 \mu \mathrm{g} / \mathrm{g}, \mathrm{Zn} 63.4 \mu \mathrm{g} / \mathrm{g}$, Fe $182.6 \mu \mathrm{g} / \mathrm{g}, \mathrm{Pb}$ $2.3 \mu \mathrm{g} / \mathrm{g})$ and Kapusta et al. (2006) (Cd $6.44 \mu \mathrm{g} / \mathrm{g}, \mathrm{Pb}$ $5.64 \mu \mathrm{g} / \mathrm{g}, \mathrm{Zn} 304 \mu \mathrm{g} / \mathrm{g})$. When compare the results of these studies, especially in Turkey, it can be concluded that the concentrations of $\mathrm{Pb}$ and $\mathrm{Cd}$ display close values. However, large differences in iron values are noteworthy.

The high concentration of trace elements in soils is reflected by higher concentrations of metals in plants, and consequently in animal and human bodies (Buszewski et al. 2000). Bowen (1979) has reported the normal natural concentration intervals for land plants as $\mathrm{Cd} 0.2-2.4 \mu \mathrm{g} / \mathrm{g}$, $\mathrm{Ni} \quad 1-5 \mu \mathrm{g} / \mathrm{g}, \quad \mathrm{Zn} \quad 20-400 \mu \mathrm{g} / \mathrm{g}$, Fe 70-700 $\mu \mathrm{g} / \mathrm{g}, \quad \mathrm{Pb}$ $1-13 \mu \mathrm{g} / \mathrm{g}$, Mn 20-700 $\mu \mathrm{g} / \mathrm{g}$. Comparison of results (Table 2, 3) with other researchers findings clearly shows that obtained values are suitable for the accepted range determined by Bowen (1979). Hence, the area studied is free from the contamination of trace element pollution concerning the trace elements investigated.

Baslar et al. (2009) have obtained the following results in their study, conducted on Honaz, another important mountain of the same region. The mean concentrations determined at $1,000 \mathrm{~m}$ altitude ranged between 0.273 and 0.488, 0.099 and 0.488, 0.306 and 0.682, 1.017 and 3.744, and 0.148 and $0.674 \mu \mathrm{g} / \mathrm{g}$, dry weight, for $\mathrm{Pb}, \mathrm{Ni}, \mathrm{Zn}, \mathrm{Fe}$ and $\mathrm{Mn}$, respectively. At $1,600 \mathrm{~m}$ altitude, the values ranged between 0.225 and $0.534,0.150$ and $0.842,0.234$ and $0.905,1.082$ and 3.864 and 0.023 and $0.982 \mu \mathrm{g} / \mathrm{g}$, dry weight for $\mathrm{Pb}, \mathrm{Ni}, \mathrm{Zn}, \mathrm{Fe}, \mathrm{Pb}$ and $\mathrm{Mn}$, respectively. No $\mathrm{Cd}$ was detected at both altitudes. Moreover, Kula et al. (2010) have studied on trace element concentrations of plants (such as Cistus laurifolius L., Euphorbia stricta L., Quercus cerris L. subsp. cerris, Pinus brutia Ten., Viscum album L.) in Mt. Akdag and have obtained following results: The mean concentrations determined at $1,000 \mathrm{~m}$ altitude ranged from 0.011 to $0.882,0.241$ to $0.714,0.532$ to $9.396,0.329$ to 0.487 , and 0.155 to $3.439 \mu \mathrm{g} / \mathrm{g}$, dry weight, for $\mathrm{Ni}, \mathrm{Zn}, \mathrm{Fe}, \mathrm{Pb}$ and $\mathrm{Mn}$, respectively. At $1,600 \mathrm{~m}$ altitude, the values ranged from 0.092 to 0.600 , 0.272 to $0.834,1.130$ to $8.021,0.263$ to 0.889 and 0.076 to $0.508 \mu \mathrm{g} / \mathrm{g}$, dry weight, for $\mathrm{Ni}, \mathrm{Zn}, \mathrm{Fe}, \mathrm{Pb}$ and $\mathrm{Mn}$, respectively. No $\mathrm{Cd}$ was detected at both altitudes. Besides these studies, Yildiz et al. (2010) have studied on trace element concentrations of plants (such as Delphinium peregrinum L., Erysimum caricum L., Juniperus oxycedrus L. ssp. oxycedrus, Pistacia terebinthus L., Spartium junceum L.) in Mt. Bozdag and have obtained following results: The mean concentrations determined at $1,000 \mathrm{~m}$ altitude ranged from 0.025 to $1.609,0.232$ to $0.731,0.578$ to $5.983,0.287$ to 0.565 and 0.176 to $2.659 \mu \mathrm{g} / \mathrm{g}$, dry weight, for $\mathrm{Ni}, \mathrm{Zn}, \mathrm{Fe}, \mathrm{Pb}$ and $\mathrm{Mn}$, respectively. At $1,600 \mathrm{~m}$ altitude, the values ranged from 0.023 to $0.939,0.258$ to $1.254,0.839$ to $5.176,0.301$ to 1.341 and 0.405 to $3.351 \mu \mathrm{g} / \mathrm{g}$, dry weight, for $\mathrm{Ni}, \mathrm{Zn}, \mathrm{Fe}, \mathrm{Pb}$ and $\mathrm{Mn}$, respectively. No $\mathrm{Cd}$ was detected at both altitudes. The similarities of the results obtained from Mt. Honaz, Mt. Akdag, Mt. Bozdag and Mt. Murat show the validity and credibility of all studies.

Some plant species (such as A. fulvescens, Cupressus sempervirens, Cupressus arizonica, Pinus halepensis) are more convenient for biomonitoring of atmospheric deposition of pollutants (Baycu et al. 2006; Kaya and Yaman 2008). The ability of these plants to absorb and accumulate xenobiotics makes them useful as indicators of environmental pollution (Buszewski et al. 2000). These plants have been shown to be resistant to trace elements and are capable of accumulating them into their roots and leaves and transporting these soil pollutants to high concentrations. Thus, biologically engineered methods designed to improve the use of phytoremediation to reduce the amount 
of trace elements in contaminated soils (Mudgal et al. 2010).

Phytoremediation is a technology of treating the environment in which some plant species use their large abilities to accumulate pollutants (Szyczewski et al. 2009). The plant used in the phytoremediation technique must have a considerable capacity of metal absorption, its accumulation and strength to decrease the treatment time. Many families of vascular plants have been identified as metal hyperaccumulator (Reeves and Baker 2000; Prasad and Freitas 2003), and many of them belongs to Brassicaceae (Mudgal et al. 2010). The examination of plant samples used in this study in terms of accumulation values showed that the high values of A. fulvescens ssp. fulvescens, is a member of Brassicaceae family, support this opinion. Therefore, this plant can be considered as a suitable plant for phytoremediation.

In the statistical analysis, comparison of trace element pollution values of herbaceous and woody plants for $\mathrm{Ni}, \mathrm{Pb}$ and $\mathrm{Mn}$ was significant $(P<0.05)$, while it was not for $\mathrm{Fe}$ and Zn (Table 4). Kula et al. (2010) found the difference between the values of $\mathrm{Fe}, \mathrm{Pb}$ and $\mathrm{Mn}$ from herbaceous and woody plants of Mt. Akdag statistically significant, while Yildiz et al. (2010) found the values of Fe and Mn statistically significant in their work on Mt. Bozdag. When compare the results of this study with those of above two studies, it can be concluded that especially the concentration of Mn displays statistically significant difference between herbaceous and woody plants of the area.

\section{Conclusion}

In the present study, the plants used as biomonitor to investigate the levels of the trace elements $\mathrm{Cd}, \mathrm{Ni}, \mathrm{Zn}, \mathrm{Fe}$, $\mathrm{Pb}$ and $\mathrm{Mn}(\mu \mathrm{g} / \mathrm{g}$, dry weight), were sampled with 29 different species at two different heights $(1,000$ and $1,600 \mathrm{~m})$ in the Mt. Murat. The results proved that the plants selected by this study accumulate some metals in assimilation organs and roots. Thus, some of these plants (such as A. fulvescens ssp. fulvescens) can be recommended as indicators for determination of pollution levels of the environment.

Metal accumulation level in plants, an important parameter in the appreciation of lendable species for phytoremediation process, demonstrate that some of analyzed species are good accumulators, but because of quite low accumulation level these species are not efficient in the hard-polluted soil bioremediation.

Techniques related to phytoremediation is still in its early development stages and full scale applications are still limited. For prevalent future use of this technique, it is important that public awareness about this technology is considered and clear and definite information is made available to the general public to enhance its acceptability as a global sustainable technology to be widely used.

The contamination of environment by trace elements causes a serious problem because they cannot be naturally degraded like organic pollutants and they accumulate in different parts of the food chain. So, application of the established sampling procedures and determination methods for xenobiotics in environmental samples can be successfully applied for the purpose of analyses in biomonitoring

Acknowledgments The authors also wish to extend their sincere gratitude to all who assisted in promoting the present work.

\section{References}

Aksoy A, Sahin U, Duman F (2000) Robinia pseudo-acacia L. as a possible biomonitor of heavy metal pollution in Kayseri. Turk J Bot 24:279-284

Alfani A, Baldantoni D, Maisto G, Bartoli A, Virzo De Santo A (2000) Temporal and spatial variation in C, N, S and element contents in the leaves of Quercus ilex with in the urban area of Naples. Environ Pollut 109(1):119-129

Anonymous (1996) Analysis of plant tissue: wet digestion. In: Analytical methods for atomic absorption spectroscopy. Perkin Elmer, Inc. USA, pp 141-143

Bargagli R (1998) Trace elements in terrestrial plants: an ecophysiological approach to biomonitoring and biorecovery. Springer, New York

Bargagli R, Monaci F, Agaorelli C (2003) Oak leaves as accumulators of airborne elements in an area with geochemical and geothermal anomalies. Environ Pollut 124(2):321-329

Baslar S, Dogan Y, Bag H, Elci A (2003) Trace element biomonitoring by needles of Pinus brutia from Western Anatolia. Fresen. Environ. Bull 12(5):450-453

Baslar S, Dogan Y, Yenil N, Karagoz S, Bag H (2005) Trace element biomonitoring by leaves of Populus nigra L. from Western Anatolia, Turkey. J Environ Biol 26(4):665-668

Baslar S, Kula I, Dogan Y, Yildiz D, Ay G (2009) A study of trace element contents in plants growing at Honaz Dagi-Denizli. Turkey. Ekoloji 18(72):1-7

Baycu G, Tolunay D, Ozden H, Gunebakan S (2006) Ecophysiological and seasonal variations in $\mathrm{Cd}, \mathrm{Pb}, \mathrm{Zn}$ and $\mathrm{Ni}$ concentrations in the leaves urban deciduous trees in Istanbul. Environ Pollut 143(3):545-554

Blok J (2005) Environmental exposure of road borders to zinc. Sci Total Environ 348(1-3): 173-190

Bowen HJM (1979) Environmental chemistry of the elements. Academic Press, London, New York

Brandys J, Gawlik M, Moniczewski A., Rutkowska A, Starek A. (1999) Toxicology, selected aspects. (in Polish). Jagiellonian University Press, Cracow

Buszewski B, Jastrzebska A, Kowalkowski T, Gorna-Binkul A (2000) Monitoring of selected heavy metals uptake by plants and soils in the area of Torun, Poland. Pol J Environ Stud 9(6):511-515

Calzoni Gl, Antognoni F, Pari E, Fonti P, Gnes A, Speranza A (2007) Active biomonitoring of heavy metal pollution using Rosa rugosa plants. Environ Pollut 149(2):239-245

Cayir A, Coskun M, Coskun M (2008) Concentrations of some elements in the bioindicator organism Cladonia rangiformis collected at the vicinity of Canakkale. Ekoloji 18:7-13 
Davis PH (1965-1985) Flora of Turkey and the East Aegean Islands, vols 1-9. Edinburg University Press, Edinburg

Davis PH, Mill RR, Tan K (1988) Flora of Turkey and the East Aegean Islands (Supplement), vol 10. Edinburg University Press, Edinburg

Dijingova R, Wagner G, Peshev D (1995) Heavy metal distribution in Bulgaria using Populus nigra italica as a biomonitor. Sci Total Environ 172(2):151-158

Dogan Y, Durkan N, Baslar S (2007) Trace element pollution biomonitoring using the bark of Pinus brutia in the Western Anatolian part of Turkey. Trace Elem Electrolyte 24(5):146-150

Dogan Y, Ugulu I, Baslar S (2010) Turkish red pine as a biomonitor: a comparative study of the accumulation of trace elements in needles and barks. Ekoloji 19(75):88-96

Gadzala-Kopciuch R, Berecka B, Bartoszewicz J, Buszewski B (2004) Some considerations about bioindicators in environmental monitoring. Pol J Environ Stud 13(5):453-462

Guner A, Ozhatay N, Ekim T, Baser KH (2001) Flora of Turkey and the East Aegean Islands (Supplement II), vol. 11. Edinburg University Press, Edinburg

Huseyinova R, Kutbay HG, Bilgin A, Kilic D, Horuz A, Kirmanoglu C (2009) Sulphur and some heavy metal contents in foliage of Corylus avellana and some roadside native plants in Ordu Province, Turkey. Ekoloji 18(70):10-16

Kapusta P, Szarek-Lukaszewska G, Godzik B (2006) Spatio-temporal variation of element accumulation by Moehringia trinervia in a polluted forest ecosystem (South Poland). Environ Pollut 143(2): 285-293

Kaya G, Yaman M (2008) Trace metal concentrations in Cupressaceae leaves as biomonitors of environmental pollution. Trace Elem Electrolyte 25(3):156-164

Kula I, Yildiz D, Dogan Y, Ay G, Baslar S (2010) Trace element contents in plants growing at Akdag, Denizli. Biotechnol Biotechnol Eq 24(1):1587-1591

Loppi S, Giomerelli B, Bargagli R (1999) Lichens and mosses as biomonitors of trace elements in a geothermal area (Mt. Amiata, central Italy). Cryptog Mycolog 20(2):119-126

Manning WJ, Godzik B, Musselman R (2002) Potential bioindicator plant species for abidient ozone in forested mountain areas of central Europe. Environ Pollut 119:283-290

Mudgal V, Madaan N, Mudgal A (2010) Heavy metals in plants: phytoremediation: plants used to remediate heavy metal pollution. Agric Biol J N Am 1(1):40-46

Nalecz-Jawecki G, Sawicki J (1998) Toxicity of inorganic compounds in the Spirotox test-a miniaturized version of the Spirostomum ambiguum test. Arch Environ Contam Toxicol $34: 1-5$
Ng O-H, Tan BC, Obbard JP (2005) Lichens as bioindicators of atmospheric heavy metal pollution in Singapore. Environ Monit Assess 123:63-74

Nriagu JO, Pacyna J (1988) Quantitative assessment of worldwide contamination of air, water and soils by trace metals. Nature 333:134-139

Oliva SR, Rautio P (2005) Spatiotemporal patterns in foliar element concentrations in Ficus microcarpa L. f. growing in an urban area: implications for biomonitoring studies. Ecol Indic 5(2): 97-107

Onder S, Dursun S, Gezgin S, Demirbas A (2007) Determination of heavy metal pollution in grass and soil of city centre green areas (Konya, Turkey). Pol. J. Environ. Stud 16(1):145-154

Osteras AH, Ekvall L, Greger M (2000) Sensitivity to, and accumulation of, cadmium in Betula pendula, Picea abies, and Pinus sylvestris seedlings from different regions in Sweden. Can J Bot 78(11):1440-1449

Ozturk M, Yucel E, Gucel S, Sakcali S, Aksoy A (2008) Plants as biomonitors of trace elements pollution in soil. In: Prasad MNV (ed) Trace elements as contaminants and nutrients: consequences in ecosystems and human health. John Wiley \& Sons, Inc., Hoboken, pp 721-742

Prasad MNV, Freitas HMO (2003) Metal hyperaccumulation in plants-biodiversity prospecting for phytoremediation technology. Electron J Biotechnol 6(3):285-321

Reeves RD, Baker AJM (2000) Metal-accumulating plants. In: Raskin I, Ensley BD (eds) Phytoremediation of toxic metals. Wiley, NY, pp 193-229

Samura A, Al-Aghai O, Tuncel SG (2003) Study of trace and heavy metals in rural and urban aerosols of Uludag and Bursa (Turkey). Water Air Soil Pollut 3:109-126

Szczepaniak K, Biziuk M (2003) Aspects of the biomonitoring studies using mosses and lichens as indicators of metal pollution. Environ Res 93(3):221-230

Szyczewski P, Siepak J, Niedzielski P, Sobczynski T (2009) Research on heavy metals in Poland. Pol. J. Environ. Stud 18(5):755-768

Yildiz D, Kula I, Ay G, Baslar S, Dogan Y (2010) Determination of trace elements in the plants of Mt. Bozdag, Izmir, Turkey. Arch Biol Sci 62:731-738

Yilmaz S, Zengin M (2004) Monitoring environmental pollution in Erzurum by chemical analysis of Scots pine (Pinus sylvestris L.) needles. Environ Int 29(8):1041-1047

Yilmaz R, Sakcali S, Yarci C, Aksoy A, Ozturk M (2006) Use of Aesculus hippocastanum L. as a biomonitor of heavy metal pollution. Pakistan J Bot 38(5):1519-1527

Zechmeister HG (1995) Correlation between altitude and heavy metal deposition in the Alps. Environ Pollut 89(1):73-80 